\title{
Problems and prospects for the development of a public environmental control system
}

\author{
Tatyana Dalgaly ${ }^{1}$, and Marina Vanslav ${ }^{2}$ \\ ${ }^{1}$ Krasnoyarsk State Agrarian University, 117, Lenin St., Krasnoyarsk, 660049, Russia \\ ${ }^{2}$ Reshetnev Siberian State University of Technology, 31 "Krasnoyarskiy Rabochiy" pr., Krasnoyarsk, \\ 660037, Russia
}

\begin{abstract}
In Russia system of public environmental control is picking up momentum these days. It manages social relations in the field of environmental protection and rational use of natural resources. But it is not unique. It sometimes plays a crucial role, as in the case of diesel spillage in Norilsk in May 2020, but sometimes not. Natural resources have been developed all over the world for centuries with minimal environmental control. This is largely due to the fact that the adverse impact on the environment was not understood and assessed in the way it is now, and at that time the available technologies could not always prevent or control damage to the environment. The result of such unfavourable effect contaminated soils and water, flora and fauna, landscape and many others change. This article is devoted to the issues of improving the system of state and public control of environmental protection.
\end{abstract}

\section{Introduction}

In Russia technologies for the rational use of natural resources and environmental protection are developing extremely rapidly, especially in the context of the environmental crisis, which has made colossal changes in all spheres of society. In this case, it is undoubtedly important to understand the essence, goals and main tasks that the state and society were forced to face in the field of environmental protection. Public environmental control is a complex task that requires the use of special knowledge and skills. At the same time, the key problem is the lack of a unified conceptual knowledge about the content of public environmental control, as well as the difficulty in delineating the powers of various subjects of state supervision in the field of rational use of natural resources and environmental protection. In addition, there is a lack of a sufficient number of scientific and sociological studies on the history of development and the impact of public environmental control on the level of environmental protection.

The traditional system of environmental protection initially included only environmental control of state authorities over the rational use of natural resources and was compulsory. This is evidenced by the normative legal acts of the 19th-20th centuries, to which classical theoretical concepts usually refer. 
Only in the second half of the 20th century, on the basis of legislation, a truly legal basis for environmental protection began to take shape and the emergence of an integral system of state supervision and public environmental control. For the first time, the right to a favorable environment in Russia, more precisely in the USSR, was proclaimed by the Declaration of Human Rights and Freedoms, adopted in 1991 by the Congress of People's Deputies of the USSR. In the future, this right will be reflected in Art. 20 of the Constitution of the Russian Federation and other regulatory legal acts that consolidate the foundations of rational nature management and environmental protection.

The right to a favorable environment guaranteed by the Constitution of the Russian Federation [1] is ensured not only by the system of public control, but other kinds of control, such as state and industrial monitoring and others. Thus, for example, other corresponding rights and obligations of citizens - the right to demand the provision of timely, complete and reliable information about the state of the environment and measures for its protection and the obligation of state bodies to provide this information, the right to compensation for harm caused to human health and property by an environmental crime and offense and the obligation of the guilty person to incur appropriate punishment for the unlawful act, in essence, are the means of realizing the right of citizens to a favorable environment.

Thus, what existed before the legislative consolidation of the right to a favorable environment was not a system of state supervision and public control in the full sense of the word: there were no mechanisms and legal classification of means and control entities in the field. Environmental protection is the responsibility of the state. In order to ensure the effective implementation of this obligation and the corresponding right of citizens to a favorable environment, the state created the foundations of a system of public control, which is still applied. According to many authors, environmental control is one of the most effective organizational and legal means of management in the activities of executive authorities, designed to protect the environment, ensure the rational use of natural resources and prevent negative impact on the environment.

\section{Materials and methods}

As the main methods of scientific research, when writing the material, the methods of review and analysis of research works and legislation in the field of rational use of natural resources and environmental protection were used, since they contribute to the understanding of the main points of view on the problem, as well as criticism expressed on this topic. These methods help to find gaps in research and legislation, combine disparate pieces of information and detail the research topic.

A questionnaire was conducted to identify the level of development and the degree of participation of citizens of the Russian Federation in the context of public environmental monitoring. The questionnaire was carried out among 500 residents of Krasnoyarsk Krai. The questionnaire questions are presented in table 1.500 questionnaire forms were used, all of them were suitable for further analysis.

Table 1 Public opinion survey questionnaire on citizens' participation in the public environment

\begin{tabular}{cl}
\hline Number & Question \\
\hline A & Sex \\
B & Age \\
C & How do you evaluate the environmental situation in Russia? \\
D & Where do you get information on the ecological status of the state? \\
E & Have you heard of public environmental control? \\
F & Have you participated in any environmental protection activities? \\
G & Do you consider citizen participation in environmental control to be effective?
\end{tabular}


Of the respondents, $64 \%$ were female, $36 \%$ were male. As for the age category, all respondents were classified into the following three groups: up to 35 years old (40\%), from 35 to $60(45 \%)$, over 60 years old (15\%). The overwhelming majority of respondents $(85 \%)$ evaluate the environmental situation in Russia as unsatisfactory. Moreover, most often $(65 \%)$ respondents receive information about the environmental situation from the Internet, less often from conversations with knowledgeable people (19\%), based on their own observations $(10 \%)$ and from print media $(6 \%)$. The survey showed that citizens in most cases take an active civic position, since $71 \%$ of the respondents took part in some kind of environmental protection activity. At the same time, only $38 \%$ of the total number of surveyed citizens heard about public control. When asked about the effectiveness of citizens' participation in environmental control, $63 \%$ of the respondents gave a positive opinion, $21 \%$ consider such participation ineffective and $16 \%$ did not think about it.

This method of empirical research was also used as a statistical analysis of the level of environmental crime in Russia from 1997 to January-October 2020. The results of the analysis are presented in figure 1.

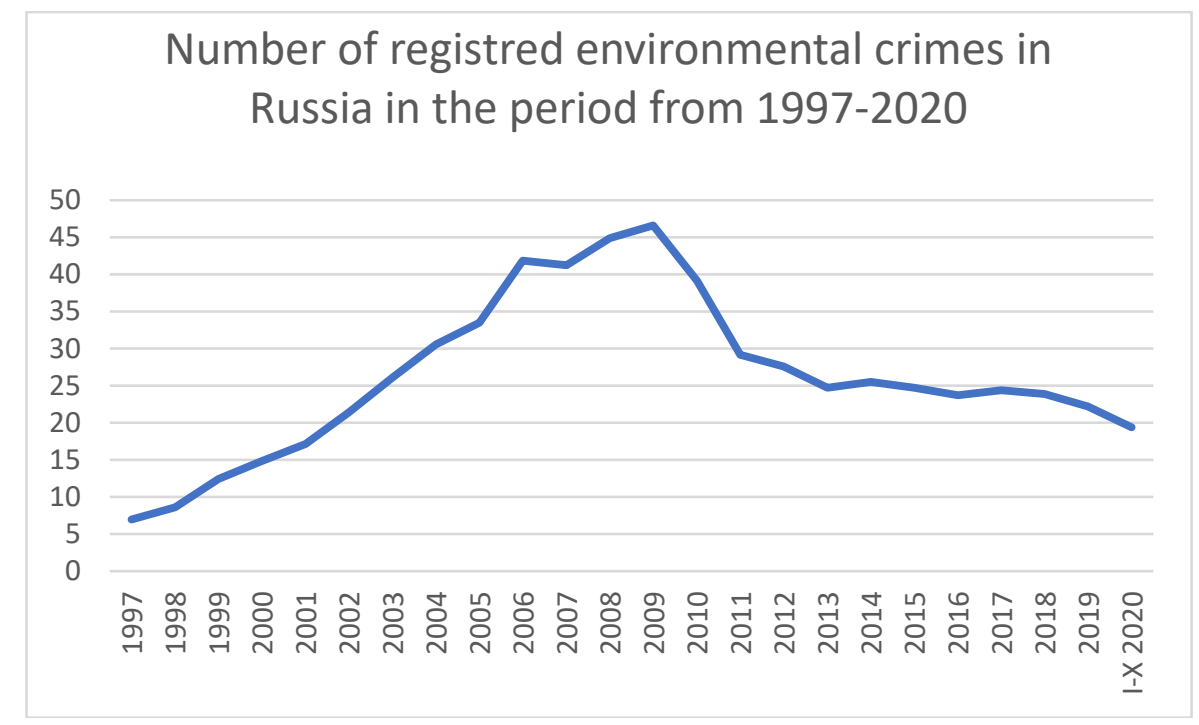

Fig. 1. The number of registered environmental crimes in Russia in the period from 1997 to 2020

\section{Research}

The starting point of the environmental control system is the main difference between its various types. Additionally, in law enforcement practice, it becomes necessary to differentiate not only the types by subjects, but also the objects to increase its effectiveness.

In historical retrospective review, the earliest regulatory legal acts on environmental control had a general nature and were applied mostly in the organization of management in the field of environmental protection. Changes in environmental legislation which were adopted for environmental management, arose much later, closely monitoring the intensity of scientific research and the practice of applying the law in this field.

In Russia, until the middle of the twentieth century, there was no term for public environmental control. Such bills or their implementation seemed to have little success. Part of the problem was the delimitation of powers between the executive authorities and subjects of public environmental control, deficiencies in legislation and so on. This conclusion is 
confirmed by the continuing strong pollution of air, water and other pollution, which continued after the specified period.

According to the Ministry of Internal Affairs of the Russian Federation, presented in Figure 1, the developing environmental crisis in Russia reached its peak in 2009, when a record number of environmental crimes was registered - 46607. At the same time, all subsequent years show an intensive decrease in the number of registered environmental crimes in more than two times - from 46607 in 2009 to 22.2 in 2019. Apart from that, according to the Ministry of Internal Affairs of the Russian Federation, 19.4 thousand crimes were registered in the period from January to October 2020, which allows us to conclude that public administration in the field of environmental protection can be recognized as effective.

The reasons of such a sharp decrease in registered environmental crimes in Russia by more than two times over the past ten years can be a whole range of measures for environmental protection. The intensity of the development of public environmental control is clearly one of the factors and conditions for the effectiveness of environmental protection. So, in order to realize the right to a favorable environment, public organizations and individual citizens are increasingly participating in the implementation of environmental control, for example, by creating environmental educational projects. The information component in protecting the environment is an important condition for the necessary reaction of citizens to situations that can harm the environmental situation of a specific area [2]. The state actively supports the initiatives of public organizations and citizens in the field of environmental protection by allocating grants and other support for scientific and other research, declaring 2017 the year of ecology, and so on. According to Sergei Donskoy, the Minister of Natural Resources and Environment, "the government is systematically and consistently working to form institutions for green financing" [3]. We are talking about the creation of a "green" bank in Russia, which will finance environmental projects. All this and much more has become a powerful motivator for activating society in the fight for a healthy environment. It should also be noted that the procedure for organizing the activities of public inspectors for environmental protection established by the Order of the Ministry of Natural Resources and Environment of the Russian Federation of July 12, 2017 [4] will significantly strengthen the presence of representatives of society in the system of state supervision. In the regions representatives of public organizations and individual citizens are actively exercising their right to obtain the status of a public inspector, which will allow them to take part in events for the protection. Undoubtedly, this contributes to the formation of an ecological culture among the population by involving citizens in environmental activities.

It is obvious that participating in such events, citizens demonstrate a positive attitude towards environmental protection and form new values, both individual and collective levels. Thanks to active participation of citizens in public environmental control, the nihilism level is reducing. Because the major factor in the environmental crisis is nihilism. By raising the awareness and competence of individuals and organizations, a higher degree of effectiveness and results could be achieved. Considering the positive experience of citizens' participation in such activities, we consider it is necessary and expedient to develop the system of environmental, education and upbringing. This task is crucial in overcoming skepticism and ignorance. And now this task is not only for the State, but also for law and society.

However, the problem that causes the greatest concern and the greatest number of questions is the problem of legal support of public environmental control. It is necessary to provide an effective legal background that existing legislation became a real regulator of relevant social relations, relations between society, the state and others. That is why, skeptical and sometimes nihilistic views related to what many people do not understand what environmental control is in general, what its purpose and the result and, in the end, what measures its effectiveness. Among other things, public environmental control is it is a means 
of finding a compromise between the state and society; which means it is highly vulnerable to public policies and other factors.

That is why the problems that were considered by many authors [5-8] as obstacles to the implementation of public environmental control, they do not have a decisive importance of the effectiveness of environmental protection today. They are insufficient number of citizens and public organizations willing to participate in public environmental control, as well as the lack of a clearly established procedure for its implementation. Moreover, the incompetence and ignorance of the subjects of public environmental control often makes it impossible to use its results in practice. However, as it can be seen from the analysis of law enforcement practice, fairly effective decisions are made with all the indicated difficulties at the legislative and law enforcement levels.

The problem of interaction between government authorities and representatives of public control is of considerable importance in improving environmental protection. Environmental protection is an integral system of many interrelated and interacting elements that will allow the most complete and effective use of all means and mechanisms. The idea of interfacing public environmental control and state activities where any conflicts between them can be resolved with the help of interaction and joint decisions, demonstrates the flexibility of positions and the huge potential for further work.

\section{Conclusions}

Present research of prospects for the development of public environmental control to ensure compliance and abidance with environmental standards in Russia showed that even despite all the efforts of the state in the field of environmental protection and the strengthening of the role in the management system for rational use of natural resources it is extremely difficult to ensure compliance of environmental protection rules. Also, the conducted research among citizens of Krasnoyarsk Krai on current issues of public environmental control allows us to conclude that it has sufficient potential, which is confirmed by the high level of awareness and initiative of citizens in matters of environmental protection. That is why the solution of the identified problems at the legislative and law enforcement levels will effectively develop the institution of public environmental control.

\section{Acknowledgements}

We thank the citizens of the Krasnoyarsk Krai for conducting research on the problem of identifying the level of development and level of involvement of citizens of the Russian Federation in the context of public environmental monitoring.

\section{References}

1. The Constitution of the Russian Federation dated 12 December 1993 (adopted by popular vote 12 December 1993; edited on 01 July 2020)

2. D.G. Domrachev, A.A. Kirillovykh and V.N. Pugach, Theoretical and Applied Ecology 2 (2020)

3. Russia wants to create a "green" bank (2017), https://rg.ru/

4. On approval of the procedure for organizing the activities of public inspectors for environmental protection (approved by Order of Ministry of Natural Resources and 
Environment of the Russian Federation No 403 from 12 July 2017)

5. O.Yu. Ganyukhina, Legal regulation of environmental control in the Russian Federation: author. dis. Cand. jurid. Sciences (2007)

6. $\quad$ L.V. Chkhutiashvili, Legal informatics 4 (2015)

7. W. Scholtz, Ibid. (2009)

8. J. Holder, M. Lee, Environmental protection, law and policy: text and materials (2007) 